\title{
Approaching Inclusion as Social Practice: Processes of Inclusion and Exclusion
}

Janne Hedegaard Hansen

Ass. Professor, Aarhus University

Charlotte Riis Jensen

Ph.D.Student, Aarhus University

Mikkel Christian Lassen

Research Assistant, Aarhus University

Mette Molbæk

Ass. Professor, VIA University College

Maria Christina Secher Schmidt

Ass.Professor, University College Copenhagen

Doi: 10.2478/jesr-2018-0011

\section{Abstract}

The article presents the results of a review of international research investigating mechanisms and processes of inclusion and exclusion as an ongoing part of social practice in a school context. The review forms part of a research project investigating the social practices of inclusive education in primary and lower-secondary education (age 6-16) in public schools as constituted by processes of inclusion and exclusion. The project aims to shift the scientific focus of research in inclusive education from the development of pedagogical and didactic practice to the importance of community construction through inclusion and exclusion processes. The project arises in context of Danish education policy, while the review looked for international research findings on the limits between inclusion and exclusion: how they are drawn, by whom, for what reasons, and for whose benefit? On the background of the review, we conclude that there seems to be a pattern of inclusive school practice leading to a specific social order that limits inclusion. The review also shows that the construction of the ideal student through various kinds of markers has a huge impact on these limits. A twin-track approach that combines research in the development of inclusive learning environments with research in the constitution of social practice in a school context will produce knowledge of the relation between inclusive school practice and the reproduction of social structures and patterns of inequality.

Keywords: exclusion, inclusion, school, social practice, learning community

\section{Introduction}

The development of inclusive schools since the 1990s on the grounds of human rights, solidarity, and democracy took its frame of reference from the Salamanca Statement (Unesco 1994) and the 
United Nations Convention on the Rights of Disabilities (UN 2006). In this context, inclusive education refers to ensuring all students participating in learning activities and being social accepted. Educational policy requiring children with special needs to be included in ordinary learning environments in public schools rather than in specialised schools targeted at special educational needs has challenged the traditional distinction between the fields of general and special education. These two distinct fields of practice are based on two bodies of educational theory - a theory of general education and a theory of special education. The same distinction is also found in the field of educational research. Our hypothesis is that the traditional distinction between general and special education reduces the approach to inclusive education to a matter of pedagogical and didactic knowledge, organisation, and collaboration between teachers and other educators.

In Denmark, the development of inclusive schools has been highly prioritised at both government and municipal level, and in the field of pedagogical and didactic practice. Several areas in the field of inclusive education have been investigated and documented in Danish and international research: first, the characteristics of effective inclusive schools (Ainscow, Booth \& Dyson 2006; Farrell 2001; Mitchell 2008) and inclusive learning communities (Egelund \& Tetler 2009; Westwood 2005; Hansen et al. 2014); second, how inclusive processes in educational, pedagogical, and didactic practice can be supported by teachers' and other educators' collaboration, supervision, classroom management, and school leadership and reorganisation (Ainscow, Booth \& Dyson, 2006; Avramidis \& Norwich 2010; Clarke, Dyson \& Millward 1998; Jensen, 2017; Molbæk 2016; Schmidt 2015, Tetler, Molbæk, \& Jensen 2016;); and third, the identification of dilemmas, barriers, and opportunities in relation to inclusive processes (Allan \& Slee 2008; Booth \& Ainscow 2002; Brantlinger 1997; Florian 2005; Nilholm \& Alm, 2010; Norwich 2013; Westwood 2005). Both in the research and in practical school-based experience, attempts have been made to develop knowledge of how different disciplines, professions, practices, and forms of knowledge can be integrated and interlinked so as to realise the political goal of inclusive schools.

A small number of schools and municipalities in Denmark have succeeded in developing inclusive education, and fewer students than previously are being placed in special schools and classes. But for the most part, the development of inclusive education is still a challenge for teachers and other educators. Not all school students meet the government targets and transition to increased inclusion. It seems that students with special needs are less engaged in both learning and social activities, and that students with special needs express lower academic self-confidence, lower academic development, and lower academic approval (SFI 2016; UVM 2016). Too many young people are not prepared for further education when they leave secondary school at the age of sixteen. In 2016, 27 per cent of students in eighth grade were found to be unready to begin a general or vocational upper secondary education, and too few students are meeting government targets for completing primary and lower-secondary school (UVM 2016). In upper secondary schools (age 16 to 19) the dropout rate is much too high, and many students do not reach the government's target for completion (SFI 2015).

\section{Approaching Inclusion}

The reasons why the gap between research knowledge and school practice remains so wide derive from a range of complex and interconnected factors. The present research project - 'Approaching Inclusion' - aims to shift the focus from understanding inclusion as a matter of the transformation of pedagogical and didactic practice to seeing it as a social practice that is in turn constituted by both inclusion and exclusion processes (Hansen 2012; Laclau 1996; Luhmann 2002). A social practice is here defined as a practice producing and reproducing norms, values, rules, and routines through social processes, interactions, and relationships leading to a specific social order (Bjerre 2015; Bourdieu 1998; Bourdieu \& Wacquant 1992; Ehn \& Löfgren 2006; Hansen 2012, 2016; Lave \& Wenger 2004).

An important prerequisite for the study of environments that favour inclusive learning is the concept of how communities are constituted. This topic has not been adequately explored in 
educational research to date. The main question here is how to develop inclusive learning environments that will ensure the learning and development of all pupils within a social practice, while managing the processes of inclusion and exclusion. The constitution of communities always presupposes the establishment of shared rules, moral, values, and norms - of a collective social identity. Individuals adapt to a collective identity by learning and following rules and principles and internalising shared understandings in order to be included. At the same time, society reflects individual difference up to a point in order to ensure all individuals' participation. The constitution of social practice is thus a negotiation between individuality and collectivity: while society reflects differences, individuals reflect a collective social identity to a certain degree (Bjerre 2015; Bourdieu et al. 1999; Hansen 2016). There are always limits to how much diversity society can accommodate before it breaks apart and its social structure is destroyed (Hansen 2012, 2016; Laclau 1996).

From this perspective, the relationship between individual and society can be seen not just in terms of society failing individuals, but also in terms of individuals failing society (Bjerre 2015). In order to secure the cohesion of a given social practice, the balance between individuality and collectivity must therefore be negotiated so as to define how much diversity a particular social practice can accommodate while securing its social structure. In other words, all communities constitute themselves through inclusion and exclusion processes. A unilateral focus on inclusion ignores the sociological point that in order to secure their own existence, communities need to place limits on what can be included and what must be excluded (Bourdieu 1998; Hansen 2012, 2015, 2016; Jenkins 2000; Laclau 1996).

Analysis of the limits to inclusion will therefore help us to uncover the processes that make specific behaviours and positioning as subjects either possible-and-meaningful or not-possible-andnot-meaningful for inclusion in a particular school or learning community. In this way a certain space can be created in which to identify the patterns that exclude those differences that would allow the creation of a more inclusive learning environment (Becker 2008; Donzelot 1995; Goffman 2014; Hansen 2016; Laclau 1996).

The constitution of communities is complex and formed by many different agents and discourses. The present research project is limited to only investigate how teachers and other educators contribute to the constitution of social practice in public schools through their professional practice, collaboration, and meaning making. By this means it explores how teachers and other professionals can impact on student participation and learning possibilities. The project began in January 2016, and the six months of fieldwork are now complete. Six different schools and twelve classes (second and eighth grade) were followed. Each classroom was observed for one week using video and field notes, and teachers and other educators were observed at various different kinds of meetings, in total 72 meetings. Our approach to fieldwork was influenced by ethnomethodology, grounded theory, and discourse theory (Bruner 1990; Laclau \& Mouffe 1995, Mead 2015).

By investigating teachers' and other educators' practice and collaboration, we were able to gain a deeper understanding of the invisible and implicit patterns in social practice that, in learning environments, limit inclusion. Such limits regulate the degree of diversity and secure the existence of a specific social practice (Bruner 1990; Hansen 2012, 2016; Mead 2015).

At the same time, we hope to identify the dominating discourses related to inclusion within the discursive field of public schools. Teachers and other educators represent a specific school culture, and are therefore part of a specific professional and theoretical way of understanding teaching and learning. The teachers' and other educators' practice and meaning making represents wider and more general discourses on professionalism, schools, teaching, and education. These discourses also affect the conditions that structure teachers' actions and meaning making (Hansen 2012; Laclau 1993; Laclau \& Mouffe 1985). Identifying the teachers' and other educators' practice and meaning making allow us to identify the discourses that they produce and reproduce through acting and constructing meaning. 


\section{Methodology}

\subsection{Research aims}

In preparation for our fieldwork, we reviewed existing research relevant to the project. We wanted to obtain an overview of international research on inclusion and exclusion processes as an ongoing part of social practice in a public school setting. Because our objective is to shift the scientific focus in educational research to the importance of the constitution of learning communities through inclusion and exclusion processes, we looked for findings on how the limits between inclusion and exclusion are drawn, by whom, for what reasons, and for whose benefit.

\subsection{Procedures}

In our search for studies of processes of inclusion and exclusion in school and classroom, we included peer-reviewed studies from 1999 to October 2016 written in English, Danish, Norwegian, and Swedish. The search was based on findings from four research databases: ERIC, Educational Research Complete, Sociological Abstracts, and the Danish Research Database. As we are conducting fundamental research rather than focusing on teaching, didactic, or pedagogical findings or specific methods to enhance inclusive practice, we used broad-based keywords in our search. These included: inclusion, exclusion, process, social practice, social acceptance, social interaction, boundaries, relation, school, classroom community, learning environment, and teaching.

The search yielded 1,257 research articles. On the basis of article titles and abstracts, 82 articles were selected for full-text screening. We followed inclusion and exclusion criteria when we read the articles.

\begin{tabular}{|l|l|}
\hline Studies included & Studies excluded \\
\hline $\begin{array}{l}\text { Qualitative and quantitative research with explicit } \\
\text { research design that coordinates with research questions }\end{array}$ & Other settings than primary and secondary school \\
\hline Primary and secondary school & Focus exclusively on special education \\
\hline Focus on both mainstream settings and special aid & $\begin{array}{l}\text { Specific programmes or methods to achieve } \\
\text { inclusion }\end{array}$ \\
\hline Analytic approach to inclusion and exclusion processes design \\
\hline Cover all children in the class & $\begin{array}{l}\text { Specific target group, i.e. learning difficulties, } \\
\text { disabilities, social class, ethnicities, or gender }\end{array}$ \\
\hline General pedagogic & Specific subject \\
\hline
\end{tabular}

Of the 82 full-text readings, thirteen articles matched the scope of our research.

As we argued at the beginning of this article, most research on inclusive education has concentrated on the development of inclusive schools and inclusive learning environments through various kinds of interventions, strategies, and methods in the broadest sense. Accordingly, the pedagogical and didactic concept of inclusion has primary focused on the pedagogical or didactic practice of inclusion. Both concept and practice are mainly based on the idea that by focusing on inclusive pedagogical and didactic action and thinking it is possible to exclude exclusion. Therefore different kind of inclusive pedagogy and didactic methods have been developed in order to realize this idea of inclusion, e.g. differentiated teaching, co-teaching, LP. Etc. Firstly, this pedagogical and didactic understanding of inclusion has not taken into account the sociological point that inclusion presupposes some form of exclusion because exclusion is the prerequisite of inclusion and therefore no social practice is entirely free from exclusion. Secondly, pedagogy and didactic methods and practice are always an integrated part of social practice in schools and cannot be separated or isolated from social practice. In other words, pedagogy and didactic methods is just one element in social practice in schools and cannot transcend the constitutive mechanism of social practice. 
Of course school practice can gradually become more inclusive by developing pedagogical and didactic practice in a more inclusive way so the limit between inclusion and exclusion, despite being ever present, can change. The point is that the limit to inclusion can be delimited but inclusion cannot be limitless.

\section{Results and Findings}

In the following, we introduce and discuss the findings of the thirteen articles we selected. Our aim here is to show the contribution of our research to the existing knowledge base regarding processes of inclusion and exclusion in school practice. We have categorised the findings into four different themes.

\subsection{Constructions of the ideal student}

Several studies find that teachers tend to construct an understanding of the ideal and normal student, to which all students are compared. Processes of inclusion and exclusion unfold without questioning this ideal. These processes are implicit, unintended, and not visible to the teachers concerned, but they lead to specific social patterns that have a huge impact on the participation possibilities for all students. Teachers support some students who do not conform to the ideal in order that they may be included, while other students remain excluded.

In order to understand how exclusion processes may occur during the development of inclusive learning environments that are intended to ensure the participation of all students, we need to understand how these processes are legitimised, in various ways and by various logics. In our review we found seven projects investigating this issue.

Arnesen, Mietola, and Lahelma (2007) point out that teachers use a kind of psychological mindset that normalises specific ways of being a student. Accordingly, articulations are developed that deal with personality, motivation, anxiety, intelligence, learning difficulties, and special needs. They further found that these understandings locate the problem with the individual and are often deficiency-oriented. When teachers talk about inclusion, they are referring to the learning community; but in order to understand and legitimise processes of exclusion, they shift focus to an individual understanding of the problem by adopting a psychological mindset. The researchers noted that the teachers they interviewed rarely talked about social class or ethnicity in sociological terms. They concluded that it was legitimate for teachers to talk about learning difficulties and individual differences, but illegitimate to talk about social class or ethnicity.

Hall et al. (2004) study how inclusion and exclusion that are embedded in discursive practice in the classroom act to position students and contribute to their social identities. They focus on what is attributed value, and on how the ideal student is constructed through these values. Hall et al. find that test are the main source of attributed value and that appropriate and ideal studentness is constructed through students' test results. They also find that teachers believe that it is the student that is responsible for their own success, and that student success is seen in terms of answering correctly in tests. Students who cannot or will not subject themselves to this practice are seen as problematic. Another consequence of the focus on tests is that teachers see students in a normative rather than a transformative perspective. Nind et al. (2004) also find that tests are used to categorise and separate pupils.

Arnesen, Mietola, and Lahelma (2007) find that an increased focus on ensuring that teachers evaluate and test student achievement in school is contrary to the inclusive school's celebration of diversity, because evaluation and tests both limit diversity and emphasise an individualistic ethos.

Waterhouse (2004) investigated the construction of the 'other' as an internal part of the constitution of social practice. He finds that the 'other' identity is constructed and sustained by teachers over the student's whole school career rather than being defined by a single event or incident. Further, the teacher categorises each child in relation to a more generalised societal normalisation frame. In local contexts, the teacher categorises each student in relation to a significant social boundary that distinguishes normal from exceptional school students. Waterhouse also finds that teachers, in a naturalistic way, use constructions of 'normal' and 'average' to refer to 
some students while others are seen as outliers. These students appear to be an ever-present concern to teachers.

Waterhouse argues that research needs to address the societal reaction rather than rulebreaking. Data shows the importance of the societal reaction in different examples. When a student labelled as exceptional acts or reacts in a normal way, they often continue to be defined by a pathological model but explained as unusual, surprising, or inexplicable. When the same student acts or reacts in an exceptional way, it is explained as expected and usual. In this way, the 'other' identity endures, because both normal and exceptional behaviour facilitate the teacher's interpretation of a classroom's social practice as normal.

Waterhouse concludes that the construction of the ideal student is used as a basis for teachers' interpretation of 'other', which is at the same time constructed as the 'ideal other'. The teachers attempt to normalise some 'others', while other 'others' are excluded.

Tuval and Orr (2009) show in their study how daily discourses and school activities serve stratification. Even though inclusion is the declared school ideology, some students are represented as weak while others are not. This dichotomy seems to be tolerated partly because the activities leading to stratification are incorporated within school routines and unnoticed, and partly because it is represented as a response to the self-evident reality of students' unequal intellectual potential. The researchers investigated how school systems create exceptional students, aiming to discern the underlying construction of the school's reality through teachers' discourses and activities.

Tuval and Orr conclude that the ideology of inclusion and the practice of stratification are incompatible, and that the discourse by which specific students are represented is based on stratification rather than diversity. The result is that some students are considered normal and others exceptional. They also conclude that academic diversity between students was represented within the schools as negative, problematic, and erratic, rather than being appreciated. For example, students who failed to acquire specific reading skills were labelled slow, and divergence from the teachers' constructions of the 'ideal' student was represented as a problem for the teacher. In evaluation meetings, teachers pronounce students to be strong or weak; low academic achievements were represented as 'lack of ability' or 'a problem of ability'. The way in which classroom space was organised itself became hierarchical, as well as students' organisation into smaller groups. Finally, even though teachers are aware of their differential behaviour towards specific students, they attribute it to the reality of the children's ability.

In general, the research included in this review identifies particular social processes in school practice that categorise and stratify students, leading to the exclusion of specific students. The construction of the ideal student through tests, values, expectations, individualisation, and potential is used as the norm to which all students are compared. The teachers develop specific expectations about the behaviour of specific students, which maintain social order in the learning community. Tests and evaluation also support these processes and set limits to inclusion.

The research surveyed in this review also shows that inclusion and exclusion processes are constructed through an individual rather than relational understanding of problems and strategies, and that a psychological mindset is dominant when exclusion needs to be legitimised in a school context.

\subsection{Students' own production of inclusion and exclusion}

Research has also been conducted into the part played by school students themselves in inclusion and exclusion processes. Benjamin et al. (2003) focus on students' interaction in inclusion and exclusion processes and with their teachers. They argue that inclusion and exclusion are complex processes, enacted moment-by-moment by students and teachers. The focus is on how students negotiate their way through these moments and how they position themselves as active members of classroom micro-cultures. Benjamin et al. attempt to understand how membership of specific categories is implicated in the production of the subjects' positions. To understand these classroom micro-cultures, the study looks beyond the local production of meaning (the classrooms themselves) and examines the wider context of the network of power relations in which that production is embedded. The study illustrates that negotiations are contingent on (although not 
determined by) a web of intersecting indices of difference. It is shown that students are active participants in these negotiations, but that the negotiations themselves are far from arbitrary. They are produced through a complex constellation of systemic indices of difference - primarily those of social class, race/ethnicity, gender/sexuality, and perceived academic ability. Berry (2006) displays how some teachers expect students to help and care for one another, thereby creating an inclusive community when the activity is classroom conversations. The dominating ethical discourse of helping one another illustrates the extent to which interdependence is the expected norm in this classroom. During whole-class lessons, students literally speak through their peers. For instance, during a whole-group lesson, one girl had raised her hand to respond to a teacher's question, but hesitated when called upon. Another girl whispered the correct response to her, and then she repeated it aloud. The teacher accepted both the answer and the behaviour saying: 'Okay, a little help from a friend'. In another classroom, this might have been considered a form of cheating.

This culture in the classroom gives opportunities for legitimate peripheral participation to students who have difficulties. But when the activity is small-group interactions, students with difficulties can be marginalised, because there is no specific support or distribution of roles (or other didacticisation) in the group. Students are largely on their own in developing relationships within their groups. The teacher merely hopes that everyone is involved in the task.

\subsection{Space and artefacts}

Gabel et al. (2013) analyse how seemingly neutral uses of words and space have the power to exclude those students who differ from the majority. For example, excluding processes take place when students have to go to another room in order to receive the right support, or when they are positioned close to the teacher to receive quick and continuous support. In this way, space places students in positions and distributes power and rights and places become landscapes of situated identity. Moreover, Gabel et al. highlight that even though students share the same space, they are a part of structures that create different positions that include and exclude the students. These findings underpin their argument that an increased attention to socio-spatial relations can lead to a change in a person's place and position, which can support practices that are more inclusive.

In line with Gabel et al. (2013), Goodfellow (2012) finds that school spaces are not neutral but co-construct students' positions. They show that space and artefacts contribute to the categorisation of students, and that these different categorisations function as a patchwork that contributes to the student's self-perception and identity. In their work, which draws on photos and narratives, they give examples of students who show photos and talk about their feelings of inadequacy and difference, for example when others are assigned the title 'Student of the Month' or when materials are classified in terms of 'age appropriateness' so as to serve as a marker for the normal.

Nind et al.'s (2004) pilot study focuses on inclusive school cultures and interactions between students and teachers, and how these relate to the larger context of national policy on inclusive education. In their search for inclusion, they were surprised to find that the exclusionary processes emerged very strongly in their data.

The data shows how the physical environment contributes to non-participation for some students. This may happen when students are sent to a different room, when they have left their books at home, or when a student's lack of participation increases to the point where they need help to complete a task, for instance being helped to find a textbook or write on the board. The study further emphasises that there seems to be a notion of the ideal student or ideal class constructed by the teacher, and that tests are used in an exclusionary way to categorise and separate students.

\subsection{The significance of relations}

According to the research included in this review, the relationship between teacher and students impacts very strongly on whether the student is at risk of being included or excluded. One study finds that teachers tend to exclude problems from the classroom by labelling and categorising 
students, and that exclusion is the most common response given the teacher's need for control in the classroom (Orsati \& Causton-Theoharis 2013). The study concludes, however, that relationships between teacher and student empower the teacher to see past the labels and learning difficulties. Teachers can support students' differences from the constructed norm by 'trusting, communicating, and listening', and this in turn impacts on the predominant discourse of exclusion as a natural and necessary meaning in action in order to sustain control in the classroom. As one teacher said: 'Most of the time I'm able to bring him down cause I've built a relationship with him... I think the key thing with these kids is building a relationship with them' (Orsati \& Causton-Theoharis 2013, p. 520).

Mamas' study (2013) of inclusive processes finds that relations between individuals and the interconnected, structural conditions of society, school, and the classroom constitute important barriers to inclusion. The study points out that the medical model is still prevalent within the inclusion discourse. It urges that more knowledge and openness in addressing the diversity of learning needs are essential. Furthermore, the study point out that inclusion seems to be a holistic and ongoing process and one which enhances the overall development of all students. The study concludes that inclusion must be understood as a continuum.

Carrington, Allen, and Osmolowski (2007) report on a participatory action research project exploring students' use of photographs as a research strategy for understanding the processes of inclusion and exclusion in their school. The focus is on relationships with peers and with their teachers. The researchers recommend that the photos taken by the students should centre on identity, position in the group, social networks, class groupings, hierarchies, relationships, achievement, failure, support, learning, leisure, sport, and spaces in the environment. The students' own narratives indicate that they want to be valued and respected and to be a part of a school community where they feel they belong and can make a contribution. Additionally, the study point out that inclusion is primarily concerned with special educational needs.

Duran et al. (2013) focus on the important role of school students' social competences for whether a student is included or excluded in school practice. To test their hypothesis that students rated with high levels of social skills are subject to less disciplinary exclusion, they investigate and find a relationship between students' social skills and disciplinary exclusion. They confirm this by showing that students rated as having low social skills are 12.5 times more likely to be excluded. Furthermore, the analysis supports findings from other studies showing that there is a relation between students' individual characteristics, their scores on social skills, and the resulting risk of exclusion. Here their analysis shows that in school it is beneficial to be a girl, not having any diagnose and to come from a higher-income family. Looking to future research, they highlight that social competencies can work as mediators for inclusion, and they suggest further research on relations between social competencies and risks of exclusion in order to identify strategies to reduce processes of exclusion.

These findings underpin how the above-mentioned themes are interrelated by the continuous and implicit normative judgements of the students themselves. They also show how social practice in school can be understood through ongoing processes of inclusion and exclusion.

\section{Discussion}

A twin-track approach that combines research in the development of inclusive learning environments with research in the constitution of social practice in a school context will allow us to produce knowledge of the relation between inclusive school practice and the reproduction of social structures and patterns of inequality. It will yield a deeper understanding of whether and how inclusive schools are in fact capable of e.g. reducing social heritage, as is one of the main goals in the Salamanca Declaration- 'regular schools with this inclusive orientation are the most effective means of combating discriminatory attitudes, creating welcoming communities, building an inclusive society and achieving education for all' (UNESCO 1994, p. 9) - or whether, even though teachers and school leaders really want to develop inclusive schools, there is still a strong association between students being labelled as exceptional and coming from families with few social and economic resources. Further, we can investigate how different social and economic groups are 
represented by different kinds of categories, or how students from families with different economic and social resources are supported in their focus on school and learning in inclusive learning environments.

Investigating the relation between inclusive school practice and the reproduction of social structures and stratification, then, the question is how the idea of the inclusive school can challenge schools' way of reproducing social heritage, normally legitimised through pedagogical and didactic reasons and perspectives, in order to develop school practice that in fact reduces social heritage. From this point of view, rather than including students with special needs, inclusion is about constructing social practices in a school context which ensure that all students have the same possibilities to participate and be educated. Rather than focusing on pedagogical and didactic practice and improving collaboration between teachers and other educators, these strategies are a matter of improving and qualifying the handling of both inclusion and exclusion processes as part of developing inclusive learning environments.

In our investigation of both inclusion and exclusion processes, we thus need to identify how and which differences are given attention when teachers and other educators construct the limits to inclusion. In this work, focus on both acting, meaning-making, semantics and artefacts as well as space seems to be important in order to give more attention to the constitutive processes of inclusion and exclusion. Identifying all parts of and levels in the constitution of social practice in a school context, the aim is to pursue and rethink inclusive education as more than a question of pedagogical and didactic strategies and methods.

\section{Conclusion}

Of the 1,257 articles surveyed, thirteen relate to the question of the constitutive mechanism of social practice through processes of inclusion and exclusion. These thirteen articles - twelve qualitative studies and one quantitative study - can be categorised into four central themes. (1) Investigation of how teachers' actions, teaching, and meaning making impact on student participation through analyses of the construction of otherness, normality, deviance, discourses, stratification, and representation. (2) Investigation of how students themselves impact on inclusion and exclusion processes in public schools and how the students themselves are active in these processes - also when it comes to meeting the expectations of being exceptional. (3) Investigation of how artefacts, space, and organisation impact on student participation and inclusion. (4) Investigation of how relations between teachers and students and among students impact inclusion and exclusion processes in public schools.

Across the studies, there seems to be a pattern of school practice constructed through negotiation of norms, values, rules, and routines through social processes, interactions, and relationships, leading to a specific social order that limits inclusion. The studies also show that the construct of the ideal student through various kinds of markers has a huge impact on these limits.

Also across the studies, there seems to be a pattern of school practice reproducing social stratification and social power structures related to social and economic inequality, gender og ethnic through pedagogical and didactic practice and teachers' and other educators' procedures that legitimises these patterns. These tendencies are not surprising or representative of new knowledge as such. But in relation to educational research in the field of inclusion, these findings are important and not always given enough attention. This might be because the focus in pedagogical research on developing a more inclusive educational practice has not in general taken into account how learning communities are established through both inclusion and exclusion processes. From a sociological perspective, it is important to underline that as we explore inclusion and how we can develop inclusive learning environments, these underlying and self-evident patterns must be identified and made visible so that they are capable of being influenced. If the fundamental mechanism of social practice is not taken into account when investigating how to develop inclusive pedagogical and didactic practice, the inclusive pedagogical and didactic practice will most likely fail. 


\section{References}

Ainscow, M., Booth, T., \& Dyson, A. (2006). Improving Schools, Developing Inclusion. London: Routledge.

Allan, J., \& Slee, R. (2008). Chapter nine: Doing Inclusive Education Research. In S. Gabel \& S. Danfort (Eds.), Disability \& the Politics of Education: An International Reader, 141-159. New York: Peter Lang Publishing.

Arnesen, A., Mietola, R., \& Lahelma, E. (2007). Language of inclusion and diversity: Policy discourses and social practices in Finnish and Norwegian schools. International Journal of Inclusive Education, 11(1), 97110

Avramidis, E., \& Norwich, B. (2010). Teachers' attitudes towards integration / inclusion: A review of the literature. European Journal of Special Needs Education, 17(2), 129-147.

Becker, H. (2008). Outsiders. Copenhagen: Hans Reitzel.

Benjamin, S., Nind, M., Hall, K., Collins, J., \& Sheehy, K. (2003). Moments of Inclusion and Exclusion: Pupils negotiating classroom contexts. British Journal of Sociology of Education, 24(5), 547-558.

Berry, R. A. W. (2006). Inclusion, Power, and Community: Teachers and Students Interpret the Language of Community in an Inclusion Classroom. American Educational Research Journal, 43(3), 489-529.

Bjerre, J. (2015). Inklusion: fra sociologisk begreb til performativ selvmodsigelse. Cursiv, 15, $125-142$. København: Aarhus Universitet. (Bjerre, J. (2015). Inclusion: From a sociological concept to a performative contradiction in terms. Cursiv, 15, 125-142. Copenhagen: Aarhus University.

Booth, T., \& Ainscow, M. (2002). Index for Inclusion, CSIE

Bourdieu, P. (1998). Practical reason, on the theory of action. Cambridge: Polity

Bourdieu, P., \& Wacquant, L. J. D. (1992). An invitation to reflexive sociology. Chicago: University of Chicago Press.

Bourdieu et al. (1999). The Weight of the World: Social Suffering in Contemporary Society. Cambridge: Polity Press, Blackwell Publishers.

Brantlinger, E. (1997). Using Ideology: Cases of Non-recognition of the Politics of Research and Practice in Special Education. Review of Educational Research, 67(4), 425-59.

Bruner, J. (1990). Acts of meaning, four lectures on mind and culture. Cambridge, Mass: Harvard University Press.

Carrington, S., Allen, K., \& Osmolowski, D. (2007). Visual narrative: A technique to enhance secondary students' contribution to the development of inclusive, socially just school environments - lessons from a box of crayons. Journal of Research in Special Educational Needs, 7(1), 8-15.

Clarke, C., Dyson, A., \& Millward. A. (Eds.) (1998). Theorizing Special Education, London \& New York: Routledge.

Donzelot, J. (1995). Promoveringen af det sociale. Dansk Sociologi, 6(3), 92-124.(Donzelot, J. (1995): Promotion of Sociality. Copenhagen: Danish Sociologi, 6(3), p. 92-124)

Duran, Jaime B., Zhou, Qiong, Frew, Leigh Ann, Kwok, Oi-Man, \& Benz, Michael R. (2013). Disciplinary exclusion and students with disabilities: The mediating role of social skills. Journal of Disability Policy Studies, 24(1), 15-26.

Egelund, N., \& Tetler, S. (2009). Effekter af specialundervisning. Copenhagen: Danmarks Pædagogiske Universitetsforlag.(Egelund, N. And Tetler, S. (2009): The Effects of Special Education. Emdrup: DPU)

Ehn, B., \& Löfgren, O. (2006). Kulturanalyser. Århus: Forlaget Klim. (Ehn, B., \& Löfgren, O. (2006). Cultural Analysis. Århus: Forlaget Klim).

Farrell, P. (2001). Special Education in the Last Twenty Years: Have Things Really Got Better? British Journal of Special Education, O(29).

Florian, L. (2005). Inclusive Practice: What, Why and How? In K. Topping \& S. Maloney (Eds.). Inclusive Education, 13-26. London: Routledge

Gabel, S., Cohen, L., Carie J., Kotel, K., \& Pearson, H. (2013). Intellectual Disability and Space: Critical Narratives of Exclusion. Intellectual and Developmental Disabilities, 51(1), 74-80.

Goffman, E. (2014). Stigma. Copenhagen: Samfundslitteratur.

Goodfellow, A. (2012). Looking Through the Learning Disability Lens: Inclusive Education and the Learning Disability Embodiment, Children's Geographies, 10:1, 67-81, DOI: 10.1080/14733285.2011.638179

Hall, K., Collins, J., Benjamin, S., Nind M., \& K. Sheehy (2004). SATurated Models of Pupildom: Assessment and Inclusion/Exclusion. British Educational Research Journal Vol. 30, No. 6, December 2004

Hansen, J. H. (2016). Social imaginaries and inclusion. In M. A. Peters (Eds.), Encyclopedia of educational philosophy and theory. Singapore: Springer, pp. 1-6.

Hansen, J.H., Andersen, B.B., Højholt, A., Morin, A. (2014). Afdækning af forskning og viden i relation til ressourcepersoner og teamsamarbejde. Undervisningsministeriet.

(Hansen, J.H., Andersen, B.B., Højholt, A., Morin, A. (2014). Review of Research and Knowledge in relation to Educators and Teamwork. Copenhagen: The Danish Ministry of Education) 
Hansen, J. H. (2012). Limits to Inclusion. International Journal of Inclusive Education, 16(1), 89-98.

Hilt, L. T. (2015). Included as Excluded and Excluded as Included: Minority Language pupils in Norwegian Inclusion Policy, International Journal of Inclusive Education, 19:2, 165-182,

Hilt, L. T. (2016). 'They Don't Know What it Means to be a Student': Inclusion and Exclusion in the Nexus Between 'Global' and 'Local'. In: Policy Futures of Education, 2016, Vol. 14(6) 666-686

Jensen, C., R. (2017) Vejledning af lærere - en samskabende proces. Når lærere støttes i at udvikle inkluderende læringsmiljøer. Ph.d.-afhandling, Copenhagen: Institut for Uddannelse og Pædagogik, Aarhus Universitet. (Jensen, C. R. (2017) Supervision with teachers - a collaborative process: When teachers are supported to develop inclusive learning environments. PhD thesis. Copenhagen: Aarhus University)

Jenkins, R. (2000). Categorisation: Identity, social process and epistemology. Current Sociology, 48(3), 7-25.

Laclau, E. (1993). Discourse. In: R.E. Goordin and P. Petitt (Eds.). A Companion to Contemporary Political Philosophy. London: Blackwell

Laclau, E. and C. Mouffe (1985): Hegemony and Socialist Strategy. London: Verso,

Lave, J., \& Wenger, E. (2004). Situeret Læring og andre tekster. Copenhagen: Hans Reitzels Forlag. (Lave, J., \& Wenger, E. (2004). Situated learning and other texts. Copenhagen: Hans Reitzels Forlag.

Luhmann, N. (2002). Inklusion og eksklusion, Tidsskriftet Distinktion, no. 4.121-139.(Luhmanm, N. (2002): Inclusion and Exclusion. Copenhagen: Distinction. No. 4.121.139

Mamas, C. (2013). Understanding Inclusion in Cyprus. European Journal of Special Needs Education, 28(4), 480-493.

Mead, G. H. (2015). Mind, Self \& Society: the Definitive Edition, Chicago and London: University of Chicago Press.

Mitchell, D. (2008). What Really Works in Special and Inclusive Education. London: Routledge.

Molbæk, M. (2016). Inkluderende klasse-og læringsledelse. Ph.d.-afhandling, Copenhagen: Institut for Uddannelse og Pædagogik, Aarhus Universitet. (Molbæk, M. (2016). Inclusive Teaching Strategies. PhD thesis. Copenhagen: Aarhus University)

Nilholm, C. \& Alm, B. (2010). An Inclusive Classroom? A Case Study of Inclusiveness, Teacher Strategies, and Children's Experiences. European Journal of Special Needs Education, (3), 239-252.

Norwich, B. (2013). Addressing Tensions and Dilemmas in Inclusive Education: Living With Uncertainty. New York: Routledge.

Orsati, F., \& Causton-Theoharis, J. (2012). Challenging control: Inclusive teachers' and teaching assistants' discourse on students with challenging behaviour. International Journal of Inclusive Education, 1-19.

Schmidt, M. C. S. (2015). Inklusionsbestræbelser i matematikundervisningen: en empirisk undersøgelse af matematiklærerens klasseledelse og elevers deltagelsesstrategier i folkeskolen, Ph.d-afhandling, Copenhagen: Institut for Uddannelse og Pædagogik, Aarhus Universitet. (Schmidt, M. C. S. (2015). Inclusion Efforts in Mathematics Teaching. An Empirical Study of Maths Teachers' Classroom Leadership and Pupils' Participation in the Danish Public School (Primary Education): PhD dissertation. Copenhagen: Aarhus University)

SFI (2015): Forberedende tilbud og overgang til ungdomsuddannelse, Copenhagen. (The Danish National Centre for Social Research (2015): Preparatory Offers and Transition to Secondary Education. Copenhagen)

Tetler, S., Molbæk, M., \& Jensen, C. R. (2016). Inkluderende klasseledelse: en samskabende proces mellem lærer og inklusionsvejleder. I R. Alenkær (red.), Inklusionsvejlederen: udvikling af fællesskaber, 185-198. Frederikshavn: Dafolo. (Tetler, S., Molbæk, M., \& Jensen, C. R. (2016). Inclusive Teaching Strategies - a co-creative process between teacher and inclusive supervisor In R. Alenkær (Eds.), The Inclusive Supervisor - development of communities 185-198. Frederikshavn: Dafolo)

Tuval, S. \& Orr, E. (2009). Social Representations of Inclusion and Stratification: Ethnographic Research Within Two Israeli Elementary Schools, Disability and Society, 24:4, 503-516, Routledge

UN (2006). United Nations Convention on the Rights of Persons with Disabilities http://www.un.org/disabilities/documents/convention/convention_accessible_pdf.pdf

Unesco (1994) The Salamanca Treatment. Accessed August 15, 2017 http://unesdoc.unesco.org/images/0009/000984/098427eo.pdf

Waterhouse, S. (2004). Deviant and Non-Deviant Identities in the Classroom: Patrolling the Boundaries of the Normal Social World, European Journal of Special Needs Education, Vol. 19, no. 1, Routledge

Westwood, P. (2005). Adapting Curriculum and Instruction, In K. Topping \& S. Maloney (Eds.): Inclusive Education, London, Routledge

UVM (Danish Ministry of Education) (2016). Afrapportering af inklusionseftersynet - Et overblik over den samlede afrapportering. (UVM (Danish Ministry of Education) (2016). Report of the inspection regarding inclusion - an overview over the overall rapport). Accessed August 15, 2017 http://www.denoffentlige.dk/sites/default/files/suppliers/news/files/160511_pixi_version_inklusion040516w eb.pdf 